\title{
Economic and legal incentives to develop fish farming companies in Russia
}

\author{
Alexander Yakovlev ${ }^{1,2, *}$, and Vasiliy Mikhaylov ${ }^{1}$ \\ ${ }^{1}$ State University of Management, State and Municipal Management Department, 109542 Moscow, \\ Russia \\ ${ }^{2}$ Diplomatic Academy of the Ministry of Foreign Affairs of the Russian Federation, International and \\ National Security Department, 119034 Moscow, Russia
}

\begin{abstract}
The article considers the main economic and legal incentives that determine the development of fish farming companies in Russia. The authors analyzed the main legal acts that form the institutional environment in the industry. Among them: the Doctrine of food security, the Federal Law on aquaculture, the state program for the development of the fisheries complex, the industry program for the development of commercial aquaculture and the strategy for the development of the fisheries complex. The study presents the results of an analysis of incentives for the development of fish farming companies in various Russian regions. The role and significance of non-profit organizations in the development of aquaculture is determined in the research.
\end{abstract}

\section{Introduction}

Fish farming as a sector of agriculture has attracted attention from state authorities. This is expressed by the formation of "game rules" that affect the development of the industry. The conditions created by the state for the development and interaction of the state with industry are reflected in the improvement of fish farming production in Russian regions and the country as a whole.

Traditionally 2 main categories of incentives affecting development are distinguished - formal and informal. Formal are laws, decrees, regulations, programs and other legal acts. For their violation established corresponding liability. Informal - not enshrined in legal sphere. Their non-observance can only entail discussion on the part of society or certain groups.

The construction of a favourable environment for the development of fish farming companies largely consists in creating conditions conducive to reducing production and transaction costs for them. This is the most important factor in increasing the efficiency of their activities. Since fish farming companies are mainly representatives of small and medium-sized enterprises it is they who are most dependent on the level of development of the legal environment in local markets.

\footnotetext{
* Corresponding author: gosypravlenie@yandex.ru
} 


\section{Research materials and methods}

The stated theme, despite its relevance, does not often become the subject of researches in Russian. More often Russian researches pay attention to general and specific problems of management $[1 ; 8]$, economics $[10 ; 12 ; 13]$ and law [5-7]. Less common we can find articles on the theme of functioning companies with state $[4 ; 19 ; 20]$ or private $[2-3]$ participation, agricultural market development [11] and food security [9].

These facts make the study on the stated topic relevant.

There are the following mane federal acts on development of fish farming companies in Russia:

- The Federal Law “On aquaculture (fish farming)... " [17];

- The Doctrine of food security [15];

- The development strategy of the fisheries complex of the Russian Federation for the period until 2030 and the plan for its implementation [14];

- The state program "Development of the fishery complex"[18];

- The industry program "Development of commercial aquaculture (commercial fish farming) in the Russian Federation for 2015-2020" [16].

In addition to the federal acts regional acts are also very important for creating the necessary conditions for the development of fish farming companies (table 1).

Table 1. Legal acts on development of fish farming companies in Russian regions

\begin{tabular}{|c|c|}
\hline $\begin{array}{l}\text { Legal act on development of } \\
\text { fish farming companies }\end{array}$ & Region \\
\hline $\begin{array}{l}\text { State fish farming development } \\
\text { program }\end{array}$ & Nizhny Novgorod reg., the Rep. of Tatarstan \\
\hline $\begin{array}{l}\text { Sub-program for the development } \\
\text { of fish farming in the framework } \\
\text { of the state program for the } \\
\text { development of the fishery } \\
\text { complex of the region }\end{array}$ & $\begin{array}{l}\text { Kaliningrad reg., Khabarovsk reg., Novgorod reg., } \\
\text { Primorskiy reg., Pskov reg., the Rep. of Dagestan, the } \\
\text { Rep. of Kalmykia, the Rep. of Karelia, Tomsk reg. }\end{array}$ \\
\hline $\begin{array}{l}\text { Sub-programs for the } \\
\text { development of fish farming in } \\
\text { the framework of the state } \\
\text { program for the development of } \\
\text { several industries }\end{array}$ & $\begin{array}{l}\text { Altai reg., Amur reg., Arkhangelsk reg., Astrakhan reg., } \\
\text { Belgorod reg., Bryansk reg., Irkutsk Reg., Kaluga reg., } \\
\text { Kamchatka reg., Kemerovo reg., Khanty-Mansi } \\
\text { Autonomous district, Kirov reg., Kostroma reg., } \\
\text { Krasnodar reg., Krasnoyarsk reg., Kurgan reg., Kursk } \\
\text { reg., Ivanovo reg., Leningrad reg., Lipetsk reg., Moscow } \\
\text { reg., Murmansk reg., Nenets Autonomous district, } \\
\text { Novosibirsk reg., Omsk reg., Orenburg reg., Penza reg., } \\
\text { Perm reg., Rostov reg., Ryazan reg., Samara reg., Saratov } \\
\text { reg., Sevastopol, Smolensk reg., St. Petersburg, Stavropol } \\
\text { reg., Tambov reg., the Chechen Rep., the Chuvash Rep., } \\
\text { the Rep. of Adygea, the Rep. of Altai, the Rep. of } \\
\text { Buryatia, the Rep of Crimea, the Rep. of Khakassia, the } \\
\text { Rep. of Komi, the Rep. of Mari El, the Rep. of Mordovia, } \\
\text { the Rep. of Sakha (Yakutia), the Rep. of North Ossetia, } \\
\text { the Rep. of Tyva, Tula reg., Tver reg., Tyumen reg., } \\
\text { Ulyanovsk reg., Vladimir reg., Volgograd reg., Vologda } \\
\text { reg., Voronezh reg., Zabaykal reg., Yamalo-Nenets } \\
\text { Autonomous district, Yaroslavl reg. }\end{array}$ \\
\hline $\begin{array}{l}\text { Separate regulations governing } \\
\text { fish farming support }\end{array}$ & the Rep. of Bashkortostan, Sverdlovsk reg. \\
\hline
\end{tabular}




\begin{tabular}{|c|c|}
\hline $\begin{array}{c}\text { There are no government } \\
\text { programs, subprograms or } \\
\text { separate documents defining the } \\
\text { development of fish farming }\end{array}$ & $\begin{array}{c}\text { Chelyabinsk reg., Chukotka Autonomous district, Jewish } \\
\text { Autonomous district, Magadan reg., Moscow, Oryol reg., } \\
\text { Sakhalin reg., the Rep. of Ingushetia, the Kabardino- } \\
\text { Balkarian Rep., the Karachay-Cherkess Rep., the Udmurt } \\
\text { Rep. }\end{array}$ \\
\hline
\end{tabular}

As you can see the regions have very different view to the issue of legal support of the development of fish farming companies.

\section{Research results}

If we take a closer look at regional legal acts consolidated to the economic support for fish farming companies we will see the following.

The analysis showed that only in 2 of Russian regions - the Rep. of Tatarstan and Nizhny Novgorod reg. pay much attention to the support and development of the fish farming companies. In 3 regions the fish farming industry is singled out as an independent industry.

In the other 9 regions the fish farming industry is included in government programs for the development of the fishery complex. It also indicates the importance for the authorities of the companies involved in fish farming.

In the vast majority of Russian regions legal incentives for fish farming companies is presented by subprogramme or part of a state program for the development of several industries. Mainly it's agriculture, the fishery complex and environmental protection. In some of them support for fish farming companies is not represented by subsidies, only by tax credit. For example, in the Nenets Autonomous district authorities due to the lack of fish farming companies within a state program provide a number of tax preferences to potential producers.

In the Republic of Bashkortostan and Sverdlovsk region there are no separate state programs for the development of aquaculture (fish farming) or subprograms as part of state programs for the development of the fish farming and other industries. Nevertheless, in these regions are approved procedures for the provision of subsidies from regional budgets aimed at supporting and developing fish farming companies. In Sverdlovsk region a state program and strategy for the development of fish farming has been under development for several years. However, as for today the document was not approved.

In 11 Russian regions there are no state programs for the development of fish farming, including intersectoral programs. In those regions fish farming does not exist in the economy of the regions or poorly represented.

Thus, the analysis of legal acts on the support and development of fish farming at the federal and regional levels revealed a number of problems related to the economic and legal support of the industry. The most acute of them is the inconsistency of the authorities in the formation of a single policy and the lack of interagency cooperation in the field of fish farming development. A similar problem is observed in other sectors of the economy.

The success of the implementation of measures within the framework of state programs to support and develop aquaculture in Russian regions can be estimated by the rating of the effectiveness of regional governance. The specified rating includes many indicators. Among them the volume of production and the volume of investment in fixed assets. It characterizes the quality of governance and the formation of the institutional environment of the region.

The level of economic support for fish farming in the regions of Russia is different. A significant part of the assistance comes from the federal budget. This is confirmed by the 
following figures (Fig. 1) [18] (data are presented in US dollars at the rate of 1 dollar 72 rubles).

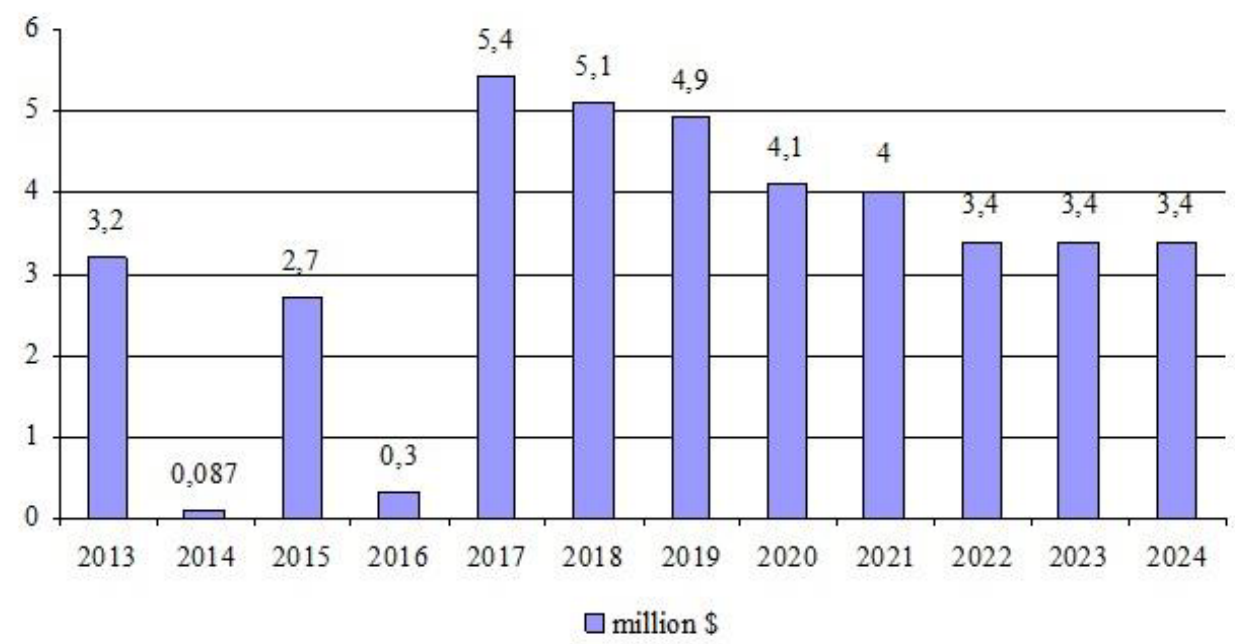

Fig. 1. The amount of budgetary funds for the implementation of the subprogram "Modernization and incentives".

As we can see in average only about 3 million US dollars a year goes to modernization and incentives of fish farming industry from the federal budget through the main subprogram for all Russian regions.

A certain role in improving the existing economic and legal incentives for the development of the industry is assigned to non-profit organizations and professional communities that provide assistance to authorities at various levels.

At the federal and regional levels various fish farming associations, unions and expert councils have been formed that carry out activities to support and develop the industry. Non-profit organizations contribute to the development of informal institutions for the development of fish farming through the formation of traditions, industry customs, high business reputation and a positive image of fish farming companies.

An example of professional community is the Association of Rosrybkhoz. It includes organizations from most of Russian regions. Its purpose is to represent and protect the interests of producers and the development of fish farming. Another organization is the Union of Sturgeons Breeders. It defines as its tasks explanatory work with all participants in the production chain up to the consumer on the legal features of sturgeon trafficking.

\section{Conclusion}

The study allowed us to draw the following conclusions.

The existing legal regulation is one of the main factors contributing to the development of fish farming companies. Federal law is a vector for the development of the fish farming industry in the Russian regions. However, it should be noted that it does not reflect regional differentiation. Therefore, it is necessary to create an environment in which effective regional support for fish farming companies is possible.

There are contradictions between the approved legal acts in terms of securing financing for the industry, expected and actual volumes of fish farming production. This may indicate the absence of a unified state policy and inconsistency of actions of authorities. 
In most Russian regions there are legal acts defining support for fish farming companies. However, their insufficient implementation in many regions negatively affects the real development of the industry.

In some regions of Russia there is no regulatory framework governing the development of fish farming. This increases their dependence on other regions and imported products and also reduces the level of regional food security.

Industry non-profit organizations and professional communities are important elements in the development of the institutional environment. It requires maximum attention and support from the authorities in order to formulate a joint policy for the development of fish farming companies

Thus, the current economic and legal incentives for the development of fish farming companies require their further expansion.

\section{References}

1. V.G.Antonov, V.V. Maslennikov, Bulletin of the University, 6, 13-22 (2014)

2. A. Borovikov, O. Smolyakov, Upravlenie, 7, 3, 54-62 (2019)

3. G. Butkovskaya, E. Sumarokova, E-Management, 2, 3, 48-57 (2019)

4. Corporate management level. Informational and educational portal in state and municipal management, Retrieved from: http://gimyrf.ru/corporativnyj_uroven/ (2020)

5. O.V. Gladysheva, V.A. Sementsov, Legal Concept, 2, 17-25 (2018)

6. I.V. Glazunova, Siberian Legal Review, 16, 4, 512-517 (2019)

7. R.D. Grebnev, The Social Science, 11, 22, 5309-5313 (2016)

8. O.B. Kozhevina, Upravlenie, 8, 1, 141-149 (2020)

9. I.M. Kulikov, I.A.Minakov, Scientific papers. Series: management, economic engineering and rural development, 19, 4, 141-147 (2019)

10. E.B. Lenchuk, Studies on Russ. Econ. Development, 27, 3, 332-340 (2016)

11. I.A. Minakov, A.V. Nikitin, International journal of innovative technology and exploring engineering, 9, 1, 3842-3847 (2019)

12. V.S. Osipov, I.I. Smotritskaya, Public service and personnel, 2, 165-169 (2016)

13. I.I. Smotritskaya, S.S. Shuvalov, Econ. and Soc. Changes: Facts, Trends, Forecast, 10, 5, 99-114 (2017)

14. The development strategy of the fisheries complex of the Russian Federation for the period until 2030 and the plan for its implementation of 27.11.2019 № 2798-r

15. The Doctrine of food security of the Russian Federation, approved by Decree of the President of the Russian Federation of 21.01.2020 № 20

16. The industry program "Development of commercial aquaculture (commercial fish farming) in the Russian Federation for 2015-2020” of 16.01.2015 № 10

17. The Federal Law "On aquaculture (fish farming) and on amendments to certain legislative acts of the Russian Federation” of 02.07.2013 № 148-FZ

18. The state program "Development of the fishery complex", decree of the Government of the Russian Federation of 15.04.2014 № 314

19. A.Y. Yakovlev, The European Proceedings of Social \& Behavioural Sciences, 76, 3376-3382 (2019)

20. A.Y. Yakovlev, Advances in Economics, Business and Management Research, 128, 2757-2760 (2020) 